\title{
Systems of Augmentative and Alternative Communication (SAACs) in Spain: A Systematic Review of the Educational Practices Conducted in the Last Decade
}

\author{
María del Mar Boillos Pereira ${ }^{1}\left(\mathbb{D}\right.$, Elizabeth Pérez-Izaguirre ${ }^{2, *} \mathbb{C}$ and Dorleta Apaolaza-Llorente ${ }^{3}$ \\ 1 Department of Didactics of Language and Literature, University of the Basque Country, 48940 Lejona, \\ Vizcaya, Spain; mariadelmar.boillos@ehu.eus \\ 2 Department of Didactics and School Organization, University of the Basque Country, 48940 Lejona, \\ Vizcaya, Spain \\ 3 Department of Didactics of Social Sciences, University of the Basque Country, 48940 Lejona, Vizcaya, Spain; \\ dorleta.apaolaza@ehu.eus \\ * Correspondence: elizabeth.perez@ehu.eus
}

Received: 19 November 2018; Accepted: 6 January 2019; Published: 10 January 2019

\begin{abstract}
Systems of Augmentative and Alternative Communication (SAACs) encompass a variety of forms of expression used to enhance the communication skills of people with disabilities and/or communication impairments. This paper compiles educational practices carried out in Spain using SAACs in the last decade. A systematic review of scientific research databases enabled a descriptive and qualitative analysis of the 25 case studies out of 88 that met the established inclusion criteria. The aim of this analysis was to obtain a global perspective of the main lines of action, as well as to identify its nature according to the beneficiary, context, aims, and typology of the SAACs implemented through the application of an evaluation grid. This evaluation grid tool arose in a broader European Project entitled AAC@ School for Social Inclusion. The results of this systematic review provide researchers and educators with evidence to apply SAACs with individuals with communication impairments, regardless of their age, gender, or the impairment or functional diversity they suffer from and could be applied in other European contexts.
\end{abstract}

Keywords: SAACs; educational practices; communication disorders; Spain; functional diversity

\section{Introduction}

Systems of Augmentative and Alternative Communication (SAACs) are the methods used to temporarily or permanently compensate for and/or enhance the communication abilities of individuals with communication impairments. SAACs increase and augment an individual's writing or speech or create alternative modes of communication (Baxter et al. 2012; Chung et al. 2012; Van der Meer et al. 2012). In a broad sense, SAACs refer to the set of strategies, including technological devices, that promote the autonomy of individuals with communication disorders, enhance their social abilities, adaptive behavior, and family relationships (McNaughton and Light 2013). An expected outcome of the use of SAACs is also an improvement in the educational service provided by practitioners who intervene with individuals who have communication impairments (Ganz et al. 2012; Light and McNaughton 2012). According to Baxter et al. (2012), the factors that affect the quality and use of SAACs include the level of complexity and reliability of the method utilized, its technical support and service provision, and family and society's attitude towards them. All of these elements should be considered by educational practitioners when choosing one SAAC over another, as SAACs constitute the principal mode of communication of individuals with communication impairments. 
Since SAACs were first referenced in the 1960s by Goldberg and Fenton, they have evolved in correspondence with societal changes (Light and McNaughton 2012, 2014). Indeed, current dynamic modes of communication have changed the primary nature of SAACs and a growing body of research addresses its complex development (Alzrayer et al. 2017; Beukelman et al. 2007; Caron et al. 2016; Flores et al. 2012; Meder and Wegner 2015; Morin et al. 2018).

For the purposes of this article, we will classify SAACs as high-tech and low-tech: whereas high-tech involves the use of an electronic and/or digital device, low-tech uses non-electronic or digital materials. More precisely, according to Baxter et al. (2012), the former refers to speech or text generating devices (SGDs, also designated as voice output communication aids, VOCA), and the latter to books, boards, pictograms, photographs and pictures (also known as picture exchange communication systems, PECSs).

The aim of this article is to systematically analyze educational practices involving the use of SAACs, including both high- and low-tech devices, in Spain, in the last ten years. In this paper, educational practices using SAACs refer to the processes involving the teaching and learning of a SAAC where the aim is to improve the communication skills and autonomy of a person with communication impairments. The analytical strategy was to research the published material referring to Spain that was available on six scientific databases within the period 2008-2018. This work describes and qualitatively analyzes diverse Spanish case studies using an evaluation grid that assesses them according to the characteristics of the beneficiaries, the context within which they took place, the type of SAACs utilized, the description of the educational practice, and the outcome obtained. The evaluation grid is contextualized in a broader European research project entitled AAC@ School for Social Inclusion (2017-1-IT02-KA201-036667) that aims to compare the use of SAACs in different contexts. Finally, this paper considers the implications of the use of such an evaluation grid and suggests its application in other European contexts to compare the results of different educational practices involving SAACs in different settings.

\section{Method}

\subsection{Search Strategy}

The databases consulted for this study were the Education Resources Information Center (ERIC), Teseo, Web of Knowledge, Scopus, Dialnet, and CSIC. A computerized search of abstracts on the six databases constituted the primary technique utilized to unearth works matching our parameters. Therefore, the search results compiled not only research papers, but also PhD Dissertations, and book chapters. The following keywords were used both in English and in Spanish: "augmentative and alternative communication", "AAC", "augmentative systems", "alternative communication".

\subsection{Inclusion Criteria}

Reading the abstracts helped to select only those works that fulfilled the inclusion criteria determined by the study: (a) conducted between 2008 and 2018; (b) developed and applied in an educational context in Spain; (c) involving an application of an augmentative and alternative communication system; and (d) included results of the application of that system. Theoretical studies were not included as the aim of this research is to better understand educational practices successfully implemented in Spain in the last ten years.

\subsection{Data Extraction}

Preferred Reported Items for Systematic Reviews and Meta Analyses (PRISMA) study flow protocol determined the data extraction and selection process of this research (Čablová et al. 2014). In line with the four steps of this protocol (identification through database searching, screening, eligibility and inclusion of the studies in qualitative synthesis), the identification process brought 88 studies, and the screening and eligibility procedures reduced the number of selected studies to 
30, as only applied educational practices were included. Other studies were excluded due to the following reasons: undefined context of application, undefined results, and repetition of other research. After refining the selection, the researchers involved in this study confirmed that 25 studies met all of the inclusion criteria. Qualitative evaluation of these studies was made following the standards of an evaluation grid, as explained below.

\subsection{Evaluation Grid}

The evaluation grid was created as part of a European project designated as AAC@ school for social inclusion and aims to reach a common framework of the principles of successful educational practices involving the use of SAACs. In this context, the evaluation grid is a tool designed to delve into the characteristics of the SAACs in practice. It functions as a methodological tool to analyze the implementation of the SAACs in each context. It also enables comparability among different case studies, based on a set of items classified as follows: target/beneficiary, context, the kind of SAACs utilized, and practice. The first category refers to the general characteristics of the individual with communication impairments. These characteristics include the kind of communication impairment he/she suffers from, his/her difficulties in social interaction, the number of beneficiaries taking part, their age, gender, ability in verbal communication and capacity to comprehend verbal/other kinds of communication, and a description of the level of communication that the individual reaches (i.e., basic needs, leisure time, family relations, etc.).

The second category addresses the context within which the case study is implemented, whether that is a special needs education center, hospital, the beneficiary's home, or another location. It also includes the barriers/opportunities in the specific context, and the social agents involved in the intervention with the beneficiary. The third category refers to the kind of SAAC utilized, the type of access that the beneficiary has to such a tool, its relationship with other communication methods, either SAACs or others, the partner(s) involved in its implementation, and if applicable, the different kinds of communication tools used with the beneficiary in distinct environments: social, family, and educational. The fourth category refers to the practice itself and takes account of the structure of the service, its duration, main goals, the type of findings related to it, the partnerships involved (i.e., public authorities, private organizations, associations or families), the funding source, the replication of such a practice, and other elements relevant to the understanding of the educational practice.

\section{Results}

As explained before, the results of this systematic review are analyzed according to the criteria established in the evaluation grid. Therefore, we will start with a profile of the beneficiaries of the SAACs, followed by a description of the context in which the SAACs are implemented. This leads to a definition of the kind of system utilized and, finally, we provide a description of the nature of the practice.

\subsection{Target/Beneficiary of the SAACs}

The participants involved in this study could be classified in four main groups according to their communication impairments. As captured in Table 1, six studies (24\%) focus on people with cerebral palsy, four studies (16\%) involve participants with autism spectrum disorder (ASD) and two studies (8\%) focus on participants with Attention Deficit/Hyperactivity Disorder (ADHD). Only one of the studies analyzed focuses on people with Alzheimer's disease. However, in later studies, the attention is not focused on the disability itself, but on the absence of communication abilities that they entail. That is why most of the studies ( $\mathrm{n}=12,48 \%$ ) develop interventions for people with severe communication impairments that could be associated with a variety of intellectual, cognitive and physical disabilities, including the aforementioned.

Although the participants in these studies have diverse communication deficiencies, they present a homogeneous profile. Toddlers or minors (0-14 years) show late, or an absence of, language 
development and adults demonstrate medium or severe communication difficulties. These difficulties bring about the absence of oral language, the use of unintelligible productions or, in some cases, the use of unaided strategies of communication such as eye-pointing or head gestures. Participants with cerebral palsy present difficulties with reading or identifying discourses, but have effectively acquired letter-sound correspondence rules (cf. Calleja et al. 2015). In all cases, communication impairments mean that participants are dependent for their basic daily needs and, in some cases, show inappropriate behaviors due to their inability to express themselves in a variety of social situations.

Table 1. Distribution of the studies according to the specific beneficiaries of the Systems of Augmentative and Alternative Communication (SAACs).

\begin{tabular}{|c|c|c|c|}
\hline Beneficiaries & $\begin{array}{l}\text { Absolute } \\
\text { Number of } \\
\text { Studies }\end{array}$ & Percentage & Study \\
\hline Cerebral palsy & $\mathrm{n}=6$ & $24 \%$ & $\begin{array}{c}\text { (Gómez-Taibo et al. 2009, 2010; Calleja et al. 2015; } \\
\text { Boquete-Jamardo and Fernández-Méndez 2015; } \\
\text { López-Vicente et al. 2016; Franco-Castellano and } \\
\text { Romero-Rodrigo 2012) }\end{array}$ \\
\hline $\begin{array}{l}\text { Autism spectrum } \\
\text { disorder }\end{array}$ & $\mathrm{n}=4$ & $16 \%$ & $\begin{array}{c}\text { (Fortea-Sevilla et al. 2015a, 2015b; Heredia-Oliva 2015; } \\
\text { Mira-Pastor and Grau-Rubio 2017) }\end{array}$ \\
\hline ADHD & $n=2$ & $8 \%$ & $\begin{array}{c}\text { (Cervera-Mérida et al. 2011; Vega-Llobera and } \\
\text { Fernández-Viader 2014) }\end{array}$ \\
\hline $\begin{array}{l}\text { Alzheimer's } \\
\text { disease }\end{array}$ & $\mathrm{n}=1$ & $4 \%$ & (Gómez-Taibo et al. 2014) \\
\hline
\end{tabular}

In $12 \%$ of the cases $(n=3)$, the age of the participants is not provided; however, the rest are distributed as shown in Table 2.

Table 2. Distribution of the studies according to the age of the beneficiaries.

\begin{tabular}{|c|c|c|c|}
\hline Range & $\begin{array}{l}\text { Absolute } \\
\text { Number of } \\
\text { Studies }\end{array}$ & Percentage & Study \\
\hline $\begin{array}{l}0-14 \text { toddlers and } \\
\text { minors }\end{array}$ & $\mathrm{n}=8$ & $32 \%$ & $\begin{array}{l}\text { (Cervera-Mérida et al. 2011; Cosía-Redondo and } \\
\text { Imbernón-López 2017; García-Martínez 2016, 2017; } \\
\text { Franco-Castellano and Romero-Rodrigo 2012; } \\
\text { Fortea-Sevilla et al. 2015a, 2015b; Mira-Pastor and } \\
\text { Grau-Rubio 2017) }\end{array}$ \\
\hline $\begin{array}{l}\text { 15-64 adolescents } \\
\text { and adults }\end{array}$ & $\mathrm{n}=7$ & $28 \%$ & $\begin{array}{c}\text { (Gómez-Taibo et al. 2009, 2010, 2017; López-Vicente et al. } \\
\text { 2016; Calleja et al. 2015; Heredia-Oliva 2015; } \\
\text { Boquete-Jamardo and Fernández-Méndez 2015) }\end{array}$ \\
\hline $\begin{array}{c}65 \text { or over elderly } \\
\text { adults }\end{array}$ & $\mathrm{n}=1$ & $4 \%$ & (Gómez-Taibo et al. 2014) \\
\hline Mixed ages & $\mathrm{n}=9$ & $36 \%$ & $\begin{array}{l}\text { (Vega-Llobera and Fernández-Viader 2014; García-Doval } \\
\text { 2013; Barragán-Valencia et al. 2009; Espejo-Cárdenas et } \\
\text { al. 2009; Vega-Guerra and Peña-Álvarez 2017; } \\
\text { Gil-Villafranca 2010; Rodríguez-Fórtiz et al. 2009; } \\
\text { Hornero et al. 2015; Sanz et al. 2017) }\end{array}$ \\
\hline
\end{tabular}

Regarding the number of cases examined in each study, four (16\%) carried out an individual case study, which means that they focus on the impact SAACs have in a specific participant and study the evolution of their communication as the system is applied (Cervera-Mérida et al. 2011; Boquete-Jamardo and Fernández-Méndez 2015; López-Vicente et al. 2016; Franco-Castellano and Romero-Rodrigo 2012; Mira-Pastor and Grau-Rubio 2017). A total of 52\% of the studies ( $\mathrm{n}=13$ ) worked with a group of participants formed of between 2 and 10 users. There are eight studies $(32 \%)$ that tackle the implementation of SAACs in large groups with $12,12,15,28,30,31,50$, and 67 users, respectively.

Finally, it is important to note that there is no discernible bias in the application of these interventions to either females or males. In fact, except for in six studies, including those with 
an individual beneficiary, the SAACs are applied to both genders and the results are presented jointly. However, in 12 studies (48\%), information on gender is not provided, thus, we can assume that the efficiency of the SAACs is not determined by a beneficiary's gender.

\subsection{Context of Application}

As we have previously mentioned, all of the selected works were implemented in Spain. However, it is interesting to observe that most of the studies were conducted in the same areas of the country: $32 \%$ in the Valencian region $(n=4), 36 \%$ in Andalusia $(n=6), 12 \%$ in Galicia $(n=3), 12 \%$ in the Autonomous Community of Madrid $(n=3), 8 \%$ in Catalonia $(n=2)$, and $8 \%$ in the Canary Islands $(n=2)$. This leads us to consider that the hubs of research initiatives in SAACs are located, mainly, in these areas of the country. In some cases, this information is not provided $(\mathrm{n}=3,15.4 \%)$ or it is too vague (cf. Gómez-Taibo et al. 2010; Sanz et al. 2017).

Generally, studies do not provide information about the characteristics of the institutions in which these interventions are applied. When mentioned, they refer to special education centers, associations for people with specific disabilities or public schools with a high percentage of disabled students, without further description.

Similarly, information about who intervenes in these studies is not usually provided. The studies that include the information specify that interventions are carried out by assistants, therapists or specialists in specific disabilities. However, in some cases, a group of various professionals is required to implement the SAAC (cf. Franco-Castellano and Romero-Rodrigo 2012). Some studies also involve families (cf. García-Martínez 2016) or the educational community (cf. García-Martínez 2017).

\subsection{Types of SAACs Utilized}

All of the studies analyzed involve the application of one or multiple SAACs with the beneficiaries. According to the classification provided, $40 \%$ of the studies $(n=10)$ apply a low-tech SAAC, including bimodal systems of communication combining sign language with oral language, pictograms, books, or boards, whereas $32 \%$ of the studies $(n=8)$ evaluated an intervention with a high-tech SAAC. The latter implemented PECs, VOCAs, mobile phone apps, or involved a broader program, such as the Treatment and Education of Autistic related Communication Handicapped Children (TEACCH), among others. TEACCH program is specifically aimed at children with ASD and involves a research-based integrated approach of visual learning cues combined with a consistent schedule and routines that aim to promote higher levels of autonomy of the beneficiaries. A total of $12 \%$ of the studies $(n=3)$ applied mixed SAACs, that is, they evaluated an intervention using both low- and high-tech devices, while $16 \%$ of the studies $(n=4)$ did not specify which SAAC was being implemented. In Table 3, we present a list of these studies:

Table 3. Classification of the types of SAACs utilized in the studies.

\begin{tabular}{|c|c|c|c|}
\hline Type of SAAC & $\begin{array}{l}\text { Absolute } \\
\text { Number of } \\
\text { Studies }\end{array}$ & Percentage & Study \\
\hline Low-tech & $\mathrm{n}=10$ & $40 \%$ & $\begin{array}{l}\text { (Boquete-Jamardo and Fernández-Méndez 2015; Calleja et al. 2015; } \\
\text { Cervera-Mérida et al. 2011; Cosía-Redondo and Imbernón-López 2017; } \\
\text { Franco-Castellano and Romero-Rodrigo 2012; García-Doval 2013; } \\
\text { Gil-Villafranca 2010; Gómez-Taibo et al. 2014; Mira-Pastor and } \\
\text { Grau-Rubio 2017; Vega-Llobera and Fernández-Viader 2014) }\end{array}$ \\
\hline High-tech & $\mathrm{n}=8$ & $32 \%$ & $\begin{array}{l}\text { (Barragán-Valencia et al. 2009; Espejo-Cárdenas et al. 2009; } \\
\text { Fortea-Sevilla et al. 2015b; Gómez-Taibo et al. 2017; Heredia-Oliva 2015; } \\
\text { Hornero et al. 2015; Rodríguez-Fórtiz et al. 2009; Sanz et al. 2017) }\end{array}$ \\
\hline Mixed & $\mathrm{n}=3$ & $12 \%$ & $\begin{array}{c}\text { (Fortea-Sevilla et al. 2015a; García-Martínez 2016; } \\
\text { Gómez-Taibo et al. 2010) }\end{array}$ \\
\hline Non-specified & $\mathrm{n}=4$ & $16 \%$ & $\begin{array}{l}\text { (García-Martínez 2017; Gómez-Taibo et al. 2010; López-Vicente et al. } \\
\text { 2016; Vega-Guerra and Peña-Álvarez 2017) }\end{array}$ \\
\hline
\end{tabular}


In most studies, the access to the SAAC being assessed was provided by the center within which the intervention took place, although $24 \%$ of the studies $(n=5)$ involving a high- or low-tech SAAC were created for the study by the authors of the papers themselves. The aim of the researchers was to assess the implementation of the new SAAC created (Barragán-Valencia et al. 2009; Calleja et al. 2015; Espejo-Cárdenas et al. 2009; Gil-Villafranca 2010; Rodríguez-Fórtiz et al. 2009).

Some studies were developed in collaboration with a research partner who provided the SAACs and the technical support. However, partnership was only mentioned in $8 \%$ of the cases $(n=2)$ (García-Doval 2013; Sanz et al. 2017). The frequency of the SAACs' implementation was explicit in $44 \%$ of the cases $(\mathrm{n}=11)$. However, in most cases, the frequency was only vaguely explained. Only $12 \%$ of the studies $(\mathrm{n}=3)$ specified that the SAAC was implemented weekly (Cosía-Redondo and Imbernón-López 2017; Cervera-Mérida et al. 2011; Fortea-Sevilla et al. 2015a).

\subsection{Nature of the Practice}

Depending on the nature of the practice, the studies did not always specify whether they were part of a greater project involving SAACs. Just $20 \%$ of the studies $(n=5)$ mentioned that they were part of a broader project (Barragán-Valencia et al. 2009; Espejo-Cárdenas et al. 2009; Franco-Castellano and Romero-Rodrigo 2012; García-Doval 2013; Sanz et al. 2017). One of those studies was a pilot project (Sanz et al. 2017).

In $44 \%$ of the studies $(\mathrm{n}=11)$, the SAAC program's duration was given, and they ranged from 4 school years in a special needs school (Vega-Llobera and Fernández-Viader 2014), 9 months (Barragán-Valencia et al. 2009), 7 months (Rodríguez-Fórtiz et al. 2009), and 4 to 1 month (Cosía-Redondo and Imbernón-López 2017; Fortea-Sevilla et al. 2015a; Gil-Villafranca 2010; Gómez-Taibo et al. 2017; Hornero et al. 2015; Sanz et al. 2017; Vega-Guerra and Peña-Álvarez 2017), to 3 weeks (Mira-Pastor and Grau-Rubio 2017).

In terms of the objective of the studies, $96 \%(n=24)$ were proposed with the aim of improving the communication skills of the beneficiaries and promoting their social interaction, whereas in one case the aim was not specified. More precisely, $8 \%(n=2)$ of the cases focused on the linguistic skills of the participants to improve their lexical competence (cf. Cervera-Mérida et al. 2011; Vega-Llobera and Fernández-Viader 2014). Furthermore, 8\% ( $n=2)$ also aimed to develop the literacy level of the participants (Gómez-Taibo et al. 2009; García-Martínez 2016), and another 8\% ( $\mathrm{n}=2$ ) were designed to improve the social integration of the persons with communication impairments. Finally, a sole case assessed the visual memory of the beneficiaries using a low-tech SAAC device (Gil-Villafranca 2010).

The results in all studies indicate that the objectives were met and reinforce the idea that SAACs enhance the communication skills of persons with communication impairments. In total, $8 \%(n=2)$ of the studies highlight that participants' social skills were improved after the implementation of the SAAC (Espejo-Cárdenas et al. 2009; Fortea-Sevilla et al. 2015a) and another $8 \%(n=2)$ address the improvement of their lexical repertoire (Fortea-Sevilla et al. 2015b; Vega-Llobera and Fernández-Viader 2014). It must also be mentioned that in one case, the conclusion section specifies that more research on the topic is needed and that the findings should be cautiously interpreted. Hence, results of this study are not easily generalized (Gómez-Taibo et al. 2009).

The funding for the implementation of these SAACs was rarely specified. Only one study mentioned that it was privately financed (Espejo-Cárdenas et al. 2009), and another that it was publicly funded (Franco-Castellano and Romero-Rodrigo 2012). Finally, according to the studies examined, only one practice involving a SAAC was transferred to another context (Barragán-Valencia et al. 2009).

\section{Discussion and Main Conclusions}

The objective of this systematic review was to examine existing research using SAACs in Spain to describe how educational practices were carried out according to the criteria proposed, the contexts in which they were developed, and the outcomes obtained. In other words, we aimed to describe current 
educational interventions involving the use of SAACs in Spain to identify the main lines of action, based on the academic literature.

The results of this review demonstrate the importance of applying SAACs with people with disabilities such as cerebral palsy, intellectual disabilities, or autism, but also people with a variety of communication impairments whose ability to communicate or to comprehend is affected. As SAACs improve both beneficiaries' autonomy and social abilities, we conclude that SAACs are beneficial to the greater society.

It is also important to point out that SAACs can be used with toddlers, young people, adults, and with the elderly. None of the studies observes that the effectiveness of these systems is affected by the beneficiaries' age and some of the interventions are applied in contexts with beneficiaries of different ages. The beneficiaries' gender does not seem to be a determining variable either. Regarding the context of application, insufficient information is provided about the institutions in which these studies were carried out or about who intervenes on these initiatives. However, we can affirm that most of the studies are performed by the same research groups.

In addition, most studies utilize either a high-tech or low-tech SAAC device or devices at the same time, and only a few of them make mixed use of them. It is meaningful to mention that in some cases, the implementation of a new SAAC developed by the research team was assessed, which involves the application and evaluation of a new educational tool. The length and frequency of use of the program involving a SAAC was either vaguely mentioned, or diverse, and could range from weeks to years of implementation.

All in all, this paper reviewed the action-oriented studies developed in Spain in the last ten years and concluded the following: in line with a variety of studies published internationally (Baxter et al. 2012; Chung et al. 2012; Van der Meer et al. 2012), this systematic review confirms that educational initiatives involving the use of SAACs and designed to improve the communication abilities of individuals with communication impairments in Spain have positive outcomes. Hence, reviewed studies reveal that educational interventions involving SAACs improve communication abilities, regardless of the type of SAAC utilized or the nature of the communication impairment suffered by the beneficiary (McNaughton and Light 2013; Ganz et al. 2012; Light and McNaughton 2012).

\section{Implications and Limitations}

An important implication of this systematic review is that, in the last 10 years, practitioners using SAACs are taking steps so as to benefit from technological advances in Spain. It would be interesting, in any case, to identify action-oriented studies developed in other European countries to contrast systems and areas of action and reflect on the most effective educational practices. A useful tool that could serve to compare different studies conducted in diverse European countries could be the evaluation grid presented, as it provides a common framework to assess different aspects of the intervention involving the use of a SAAC.

As a consequence, we also conclude that the evaluation grid is a valuable tool for having knowledge of the characteristics of the educational practices involving the use of one or multiple SAACs. In fact, it enables a comparison between different practices utilizing a SAAC according to common criteria, as specified in each of the sections. Nevertheless, it must also be mentioned that the tool does not define what constitutes an improvement in each practice and relies on the concept of improvement that each study specifies. In line with this limitation, neither does it examine the rigor of the data collected in each one of them.

The revision carried out allowed us to detect diverse limitations associated with the nature of the studies analyzed themselves. For instance, the lack of description of the context within which each intervention is carried out and the individual implementing the educational intervention involving the use of a SAAC poses a limitation. Also, educational outcomes were based on a short-term evaluation, not on long-term interventions. In line with this argument, the heterogeneity of the interventions described in the studies reviewed following the standards of the evaluation grid makes comparison of 
each of them difficult. This is due to the absence of a systematic and common framework to intervene using SAACs in Spain. Thus, comparing the results for interpretation was challenging. Moreover, all of the studies seem to be conducted with subjects having a specific set of diagnoses: cerebral palsy, Autism disorder, ADHD, or Alzheimer. In other words, studies in Spain tend to focus on individuals with these disabilities and other groups of individuals are not researched. The geographical areas in which research was conducted was limited, which implies that studies are concentrated in specific locations.

One of the unanswered questions is whether these SAACs could also be applied with people who do not have physical or intellectual disabilities. Whilst their utility has been widely proved in special education contexts, with minors and adults, none of the studies analyzed have focused their attention on other communication difficulties. A possible context of application is communication with refugees and immigrants. The European project AAC@ School for Social Inclusion, in which this study is contextualized, aims precisely at expanding SAACs to contexts such as this. Thus, new research directions should analyze current communication needs in a broader sense and investigate their implementation with beneficiaries of different profiles.

Author Contributions: All authors have equally contributed to the paper.

Funding: This research was funded by the European Commission, Erasmus + Project AAC@ School for Social Inclusion, ref. 2017-1-IT02-KA201-036667.

Conflicts of Interest: The authors declare no conflict of interest.

\section{References}

Alzrayer, Nouf. M., Devender R. Banda, and Rjinder Koul. 2017. Teaching children with autism spectrum disorder and other developmental disabilities to perform multistep requesting using an iPad. Augmentative and Alternative Communication 33: 65-76. [CrossRef] [PubMed]

Barragán-Valencia, Lorenzo, María del Carmen Martínez-Iribarne, Francisco José López-Granados, Andrea Regalado-Lao, María José Rodríguez-Fórtiz, Manuel Entrena-Casas, Andrés Pérez-Camarasa, and José Luis González Sánchez. 2009. Uso de Nintendo DS TM como recurso integrador de la “Comunicación total". Portularia: Revista de Trabajo Social 9: 17-23.

Baxter, Susan, Pam Enderby, Evans Philippa, and Simon Judge. 2012. Barriers and facilitators to use of high technology augmentative and alternative communication devices: A systematic review and qualitative synthesis. International Journal of Language and Communication Disorders 47: 115-29. [CrossRef] [PubMed]

Beukelman, David R., Susan Fager, Laura Ball, and Aimee Dietz. 2007. AAC for adults with acquired neurological conditions: A review. Augmentative and Alternative Communication 23: 230-42. [CrossRef]

Boquete-Jamardo, Alba, and Juan Carlos Fernández-Méndez. 2015. Eficacia de un sistema alternativo de comunicación en PC: Estudio caso único. Revista de Estudios e Investigación en Psicología y Educación 9: 79-84. [CrossRef]

Čablová, Lenka, Kristýna Pazderková, and Michal Miovský. 2014. Parenting styles and alcohol use among children and adolescents: A systematic review. Drugs: Education, Prevention and Policy 21: 1-13. [CrossRef]

Calleja, Marina, María Luisa Luque, José Miguel Rodríguez, and Ana Liranzo. 2015. Increasing communicative competence in two adults with Cerebral Palsy with Makey-Makey device. A case study. Revista de Investigación en Logopedia 2: 112-34.

Caron, Jessica, Janice Light, and Kathryn Drager. 2016. Operational demands of AAC mobile technology applications on programming vocabulary and engagement during professional and child interactions. Augmentative and Alternative Communication 32: 12-24. [CrossRef]

Cervera-Mérida, José F., Inmaculada Baixauli-Fortea, and Amparo Ygual-Fernández. 2011. Intervención logopédica en un caso de dispraxia verbal y trastorno por déficit de atención con hiperactividad. Revista de Logopedia, Foniatría y Audiología 31: 203-18. [CrossRef]

Chung, Yun-Ching, Erik W. Carter, and Lynn G. Sisco. 2012. Social interactions of students with disabilities who use augmentative and alternative communication in inclusive classrooms. American Journal on Intellectual and Developmental Disabilities: September 117: 349-67. [CrossRef] 
Cosía-Redondo, Cristina, and Candela Imbernón-López. 2017. La introducción de la multimodalidad comunicativa a través de la lectura de cuentos para la inclusión educativa en el Primer Ciclo de Educación Infantil. Aplicación del Programa MARTA. Indivisa. Boletín de Estudios e Investigación 17: 143-78.

Espejo-Cárdenas, Silvia, Aurelia Carrillo-Morales, Álvaro Fernández-López, and María José Rodríguez Fortiz. 2009. Estudio sobre el uso del sistema de comunicación aumentativo y aumentativo y alternativo Sc@ut. Addenda IX: 25-33.

Flores, Margaret, Kate Musgrove, Scott Renner, Vanessa Hinton, Shaunita Strozier, Susan Franklin, and Doris Hil. 2012. A Comparison of Communication Using the Apple iPad and a Picture-based System. Augmentative and Alternative Communication 28: 74-84. [CrossRef] [PubMed]

Fortea-Sevilla, María del Sol, María Olga Escandell-Bermúdez, and José Juan Castro-Sánchez. 2015a. Assessment of the efficacy of a program to improve the social communication and behavior of young children with autism spectrum disorders. Revista de Investigación en Logopedia 2: 167-85.

Fortea-Sevilla, María del Sol, María Olga Escandell-Bermúdez, José Juan Castro-Sánchez, and Juan Martos-Pérez. 2015b. Desarrollo temprano del lenguaje en niños pequeños con trastorno del espectro autista mediante el uso de sistemas alternativos. Revista de Neurología 60: 531-35.

Franco-Castellano, Ivan Franco, and Marta Romero-Rodrigo. 2012. La colaboración entre atención temprana y la escuela: Una experiencia de inclusión educativa e introducción a las nuevas tecnologías en un alumno con necesidades específicas de apoyo educativo. Edetania. Estudios y Propuestas Socioeducativas 41: 219-37.

Ganz, Jennifer B., Theresa L. Earles-Vollrath, Amy K. Heath, Richard I. Parker, Mandy J. Rispoli, and Jime B. Duran. 2012. A Meta-Analysis of Single Case Research Studies on Aided Augmentative and Alternative Communication Systems with Individuals with Autism Spectrum Disorders. Journal of Autism and Developmental Disorders 42: 60-74. [CrossRef] [PubMed]

García-Doval, Fátima María. 2013. Aportaciones Didácticas de un Tablero Digital Para Personas con Dificultades de Competencia Comunicativa. Ph.D. dissertation, University of Santiago, Santiago, Spain.

García-Martínez, María Pilar. 2016. Una Visión Comprensiva de la Realidad de los Menores que Utilizan Sistemas Aumentativos y/o Alternativos de Comunicación (SAAC) Desde los Ámbitos Familiar, Profesional e Iguales. Papel de las NNTT. Ph.D. dissertation, University of Málaga, Málaga, Spain.

García-Martínez, María Pilar. 2017. Children and Augmentative or Alternative Communication System (AACs). A perceptive vision of the role played by families and professionals. Anales de Psicología 33: 334-41. [CrossRef]

Gil-Villafranca, Ana. 2010. Sistemas aumentativos de comunicación en educación especial. Educación y Futuro 23: 21-28.

Gómez-Taibo, María Luisa, Pilar Vieiro-Iglesias, María Sotillo-Méndez, and María del Salvador González-Raposo. 2009. A descriptive study of working memory, phonological awareness and literacy performance of people who use AAC. International Journal of Special Education 24: 1-20.

Gómez-Taibo, María Luisa, Pilar Vieiro-Iglesias, María del Salvador González-Raposo, and María Sotillo-Méndez. 2010. An Exploratory Study of Phonological Awareness and Working Memory Differences and Literacy Performance of People that Use AAC. The Spanish Journal of Psychology 13: 538-56. [CrossRef] [PubMed]

Gómez-Taibo, María Luisa, Paula Parga-Amado, Nereida Canosa-Domínguez, Pilar Vieiro-Iglesias, and Teresa García Real. 2014. Conversations about self-identity in Alzheimer disease: Augmentative and Alternative Communication memory books as an aid. Revista de Logopedia, Foniatría y Audiología 34: 60-67. [CrossRef]

Gómez-Taibo, María Luisa, Marta Varela-Rey, Pilar Vieiro-Iglesias, and Teresa García Real. 2017. Teaching adults with intellectual disability to combine symbols in a reading context. Revista de Estudios e Investigación en Psicología y Educación 9: 1-5. [CrossRef]

Heredia-Oliva, Esther. 2015. El Uso del IPAD con el Programa AUGIE. ¿Mejora la Comunicación en las Personas con Autismo? Ph.D. dissertation, University of Alicante, Alicante, Spain.

Hornero, Gemma, David Conde, Marcos Quílez, Sergio Domingo, María Peña-Rodríguez, Borja Romero, and Oscar Casas. 2015. A wireless augmentative and alternative communication system for people with speech disabilities. IEEE Access 3: 1288-96. [CrossRef]

Light, Janice, and David McNaughton. 2012. The Changing Face of Augmentative and Alternative Communication: Past, Present, and Future Challenges. Augmentative and Alternative Communication 28: 197-204. [CrossRef] [PubMed] 
Light, Janice, and David McNaughton. 2014. Communicative Competence for Individuals who require Augmentative and Alternative Communication: A New Definition for a New Era of Communication? Augmentative and Alternative Communication 30: 1-18. [CrossRef]

López-Vicente, Amparo, Carla Artacho-Pérez, Néstor Jarque-Bou, Rafael Raya, Mariano Lloria, Juan-Manuel Belda-Lois, and Eduardo Rocón. 2016. Adaptive inputs in an interface for people with Dyskinetic Cerebral Palsy: Learning and usability. Journal: Technology and Disability 28: 79-89. [CrossRef]

McNaughton, David, and Janice Light. 2013. The iPad and Mobile Technology Revolution: Benefits and Challenges for Individuals who require Augmentative and Alternative Communication. Augmentative and Alternative Communication 29: 107-16. [CrossRef]

Meder, Allison, and Jane R. Wegner. 2015. iPads, Mobile Technologies, and Communication Applications: A Survey of Family Wants, Needs, and Preferences. Augmentative and Alternative Communication 31: 27-36. [CrossRef]

Mira-Pastor, Rosa, and Claudia Grau-Rubio. 2017. Alternative and augmentative communication systems (AACS) as an instrument for decreasing challenging behaviour to students with ASD: A case study. Revista Española de Discapacidad 5: 113-32.

Morin, Kristi L., Jenniger B. Ganz, Emily V. Gregori, Margaret J. Foster, Stephanie L. Gerow, Derya Genç-Tosun, and Ee Rea Hong. 2018. A systematic quality review of high-tech AAC interventions as an evidence-based practice. Augmentative and Alternative Communication 34: 104-17. [CrossRef] [PubMed]

Rodríguez-Fórtiz, María José, José Luis González, Álvaro Fernández, M. Entrena, Miguel J. Hornos, A. Pérez, A. Carrillo, and L. Barragán. 2009. Sc@ut: Developing adapted communicators for special education. Procedia Social and Behavioral Sciences 1: 1348-52. [CrossRef]

Sanz, Cecilia, Verónica Artola, Andrea Guisen, Javier Marco, Eva Cerezo, and Sandra Baldassarri. 2017. Shortages and Challenges in Augmentative Communication through Tangible Interaction Using a User-centered Design and Assessment Process. Journal of Universal Computer Science 23: 992-1016.

Van der Meer, Larah, Robert Didden, Dean Sutherland, Mark F. O’Reilly, Giulio E. Lancioni, and Jeff Sigafoos. 2012. Comparing three Augmentative and Alternative Communication modes for children with development disabilities. Journal of Developmental and Physical Disabilities 24: 451-68. [CrossRef]

Vega-Guerra, Judith, and Cristina de la Peña-Álvarez. 2017. Comunicación y memoria visual en escolares con discapacidad intelectual. Una relación clave para la intervención, Indivisa. Boletín de Estudios e Investigación 17: 179-97.

Vega-Llobera, Fátima, and María del Pilar Fernández-Viader. 2014. Mejora de la comunicación y del lenguaje oral con la ayuda visual de los signos manuales en alumnos con discapacidad intelectual. Estudio de casos. Revista de Logopedia, Foniatría y Audiología 34: 101-17. [CrossRef] 